\title{
Zastosowanie narzędzi informatycznych w komunikacji wewnętrznej w przedsiębiorstwie
}

\section{Wstęp}

Informacja stanowi jeden z fundamentów funkcjonowania nowoczesnych przedsiębiorstw w tzw. społeczeństwie informacyjnym i gospodarce, w której dominujący paradygmat to wiedza. Jest ona w związku z tym jednym z najważniejszych zasobów przedsiębiorstwa [Bieniecka 2013, s. 9], a umiejętność jej przekazywania jest istotnym elementem skutecznego zarządzania przedsiębiorstwem. Efektywne komunikowanie się wszystkich, którzy tworzą grupę otoczenia wewnętrznego, tworzy podstawę do właściwego funkcjonowania ludzi w każdej jednostce organizacyjnej. Wykorzystywanie nowych rozwiązań informatycznych jest właściwą drogą do uzupełnienia tradycyjnych narzędzi komunikacyjnych. Przyszłość jakiegokolwiek narzędzia komunikacyjnego zależy od stopnia jego integracji z pozostałymi narzędziami jakie pracownicy wykorzystują w firmie. Zmianie ulegać mogą wykorzystywane technologie, metody dostępu czy wymagania biznesowe, ale każdy z tych aspektów zdominowany zostanie przez potrzebę wymiany informacji w czasie rzeczywistym oraz w sposób najbardziej zbliżony do bezpośredniej rozmowy. Umiejętność implementacji funkcji realizujących te potrzeby jest krytycznym czynnikiem sukcesu każdego narzędzia komunikacyjnego.

\section{Zagadnienia metodologiczne}

Celem opracowania była analiza popularnych narzędzi wymiany informacji wewnątrz przedsiębiorstwa oraz ocena stopnia ich przydatności na przykładzie firmy Polskie Książki Telefoniczne (pkt.pl). Jest to przedsiębiorstwo istniejące na polskim rynku od 1993 roku. Firma działa na rynku „yellow pages”, a jej misja 
określona została jako dostarczanie efektywnych rozwiązań biznesowych i reklamowych dla firm z sektora małych i średnich przedsiębiorstw [http://static.pkt. $\mathrm{pl} /$ static/static-pkt/o-pkt.html]. Oferuje również doradztwo i rozwiązania biznesowe oraz możliwość reklamy poprzez media „online’owe”, mobilne oraz drukowane. Zajmuje się planowaniem kampanii reklamowych, tworzeniem stron dla firm (www.miniweb.pkt.pl), prowadzeniem stron w mediach społecznych (Facebook). Wraz z siostrzaną spółką ClearSense oferuje możliwość pozycjonowania stron i prowadzenia kampanii SEM. Stosowane rozwiązania umożliwiają dotarcie do klientów w Polsce i zagranicą za pomocą kanałów B2C oraz B2B. Od momentu utworzenia spółka posiada biura stałe w 12 miejscowościach. Oferta pkt.pl to produkty zróżnicowane pod względem informacji, systemu dystrybucji i zasięgu.

W wyniku przeprowadzonych badań sondażowych dokonano wyboru najbardziej skutecznych - zdaniem pracowników - informatycznych narzędzi komunikacyjnych. Materiał badawczy zebrał D. Malnowicz w kwietniu i maju 2013 roku. Sondaż diagnostyczny przeprowadzono wśród pracowników pkt.pl w centrali oraz oddziałach terenowych. W badaniach wykorzystano nielosowy (przypadkowy) dobór respondentów - 88 pracowników centrali oraz oddziałów (spośród 650 pracowników). Z 88 osób 35 świadczyło pracę w centrali spółki, a pozostałe $53 \mathrm{w}$ oddziałach.

\section{Definiowanie pojęcia komunikacja}

Komunikacja wewnętrzna to jeden z najważniejszych elementów kultury organizacji pracy w przedsiębiorstwie. Jest to forma dialogu pomiędzy różnymi szczeblami w strukturze organizacyjnej danej organizacji - pracownikami a zarządem i kierownictwem, a także działami czy oddziałami przedsiębiorstwa. Sprawna komunikacja wewnętrzna jest nierozerwalnie powiązana z procesem przekazywania informacji, a dobry przekaz informacji powinien być dla każdej firmy najważniejszy, ponieważ to od niego zależy, czy działania, decyzje strategiczne są odpowiednio wydawane [Olędzki, Tworzydło (red.) 1997, s. 85]. Dlaczego skuteczne komunikowanie się jest tak ważne? Jak powiedział Konrad Lorenz: „To co zostało powiedziane, nie musi być wysłuchane, to co zostało usłyszane nie musi być zrozumiane, to co zostało zrozumiane nie musi być zaakceptowane, to co zostało zaakceptowane nie musi być zastosowane, to co zostało zastosowane nie musi być utrwalone" [Goban 1997, s. 97].

Komunikacja wewnątrz organizacji jest jako skuteczne narzędzie zarządzania często niedoceniana, a przecież bez sprawnego porozumiewania się z pracownikami firmy nie jest możliwe jej dobre funkcjonowanie. To, jakie opinie pracownicy przekazują swoim znajomym i rodzinie wpływa na postrzeganie 
organizacji przez jej najbliższe otoczenie. Teoretycy i praktycy PR zgodnie twierdzą że komunikacja wewnątrz organizacji powinna być fundamentem wszystkich innych działań public relations [Bielawski, on-line].

\section{Wykorzystanie narzędzi informatycznych}

Firma, która decyduje się na obecność na rynku zorientowanym na potrzeby klienta musi najpierw wykazać się zdolnością do ich poznania i właściwego zinterpretowania. Niezbędnym elementem wymaganym do osiągnięcia tego celu jest sprawna wymiana pozyskanych informacji. Wsparciem okazały się wykorzystywane wewnątrz firmy nowoczesne narzędzia do komunikacji elektronicznej. W badanym przedsiębiorstwie pracownicy mieli do dyspozycji prócz spotkań bezpośrednich wiele narzędzi komunikacyjnych, a wśród nich: elektroniczną pocztę korporacyjna, chat, intranet, forum dyskusyjne, komunikator, wideokonferencje, telekonferencje, narzędzia pracy grupowej, tablice ogłoszeń.

Najczęściej wykorzystywanym narzędziem komunikacyjnym w badanym obiekcie była elektroniczna poczta korporacyjna. Korzystali z niej wszyscy respondenci. W firmie Polskie Książki Telefoniczne dominują narzędzia pozwalające na komunikację w czasie rzeczywistym (tab. 1).

Trzy pierwsze narzędzia wskazane przez respondentów są na tyle powszechne i tanie we wdrożeniu oraz późniejszym utrzymaniu, że stały się standardem w mniejszych firmach lub tych, które nie mają dużego budżetu przeznaczonego na realizację zadań związanych z komunikacją wewnętrzną. To ważne, ponieważ pokazuje, że wielkość firmy oraz wysokość budżetu nie muszą mieć wpływu na podjęcie decyzji o uruchomieniu technicznie złożonych narzędzi komunikacyjnych. Wszyscy ankietowani zadeklarowali użycie na swoim stanowisku pracy

Tabela 1

Narzędzia komunikacyjne wykorzystywane w pkt.pl [\%]

\begin{tabular}{|l|c|}
\hline Narzędzia & Wykorzystanie [\%] \\
\hline Elektroniczna poczta korporacyjna & 88 \\
\hline Intranet & 38 \\
\hline Komunikator & 35 \\
\hline Wideokonferencje & 19 \\
\hline Forum dyskusyjne & 12 \\
\hline Chat & 8 \\
\hline Telekonferencje & 4 \\
\hline Narzędzia pracy grupowej & 3 \\
\hline
\end{tabular}

Źródło: Badania własne. 
elektronicznej poczty korporacyjnej. Udział pozostałych chętnie wykorzystywanych narzędzi, tj. intranetu oraz komunikatora, wynosił odpowiednio 38 i 35\% ${ }^{1}$. Spośród wszystkich dostępnych narzędzi najmniej popularne były wideokonferencje. Wynika to ze specyfiki narzędzia, które z reguły wykorzystywane jest przez wyższe kierownictwo jako substytut podróży służbowej lub spotkania z kontrahentem. Biorąc pod uwagę fakt, że na 88 osób ankietowanych tylko 21 zajmowało stanowisko kierownicze, nie należy być zaskoczonym ze stosunkowo małej popularności tego narzędzia.

Płeć ankietowanych nie miała wpływu na wybór narzędzi stosowanych na stanowisku pracy. Wynikał on z zadań jakie były stawiane pracownikom. Bez względu na stanowisko pracy dominującymi narzędziami komunikacyjnymi były elektroniczna poczta korporacyjna, intranet oraz komunikator.

Najskuteczniejsze, w opinii respondentów, narzędzie komunikacyjne to elektroniczna poczta korporacyjna (85\% ankietowanych). Zgadza się to z przyznaną jej wysoką oceną. Aż 96\% osób oceniło to narzędzie dobrze oraz bardzo dobrze. Narzędziem komunikacyjnym sklasyfikowanym na drugiej pozycji był intranet $-65 \%$ ankietowanych oceniło go dobrze oraz bardzo dobrze. Umożliwia on zarządzanie informacją z jednego źródła, daje możliwość aktualizacji oraz modyfikacji. Dostępny on-line gwarantuje dostęp do źródeł z każdego miejsca na świecie. Jeśli zachodzi taka potrzeba, umożliwia ograniczenie dostępu części pracownikom do określonych kategorii informacji. Stanowi podręczną bazę plików, logotypów, informacji, regulaminów, postanowień i zarządzeń. Zastosowanie intranetu w znaczącym stopniu upraszcza komunikację i dystrybucję ważnych informacji wewnątrz struktury firmy [Piatkiewicz, on-line].

Komunikator wskazało 35\% pracowników. Komunikator jest dynamicznym kanałem komunikacji, gdzie wymiana informacji odbywa się w czasie rzeczywistym. Z intranetem jest już inaczej. Bez względu na szybkość jego aktualizacji, informacje mają charakter bardziej statyczny, a ewentualna komunikacja nigdy nie odbywa się w czasie rzeczywistym. Pozostałe narzędzia komunikacyjne z jakich korzystali pracownicy pkt.pl Polskie Książki Telefoniczne znacznie odstawały od liderów rankingu, np. czat oceniło tylko 8\% ankietowanych, ponad połowa spośród nich wystawiło ocenę „dobrą” oraz „bardzo dobrą”, co ogólnie jest wynikiem przemawiającym na korzyść narzędzia.

\footnotetext{
${ }^{1}$ Wyniki badań trendów i wyzwań dla komunikacji wewnętrznej przeprowadzane corocznie od 1997 roku przez firmę GFMP Management Consultants wykazały, że wśród badanych 156 firm stosowano następujące narzędzia komunikacyjne: $65 \%$ - forum dla pracowników, $63 \%$ - intranet, 50\% - chat, 27\% - media społecznościowe, $27 \%$ - wiki, $20 \%$ - blogi, $17 \%$ - blog prezesa, http:// www.proto.pl/raport_proto [28.11.2013].
} 
Od pewnego czasu zaczęły pojawiać się interaktywne, moderowane publikacje elektroniczne, w których informacja nadal pozostaje w rękach nadawcy, ale odbiorcy mogą na nią reagować. Przykładem tego typu narzędzia jest czat, który stanowi formę komunikacji między pracodawcą a pracownikami. Zastosowanie tego narzędzia wiąże się z wieloma zaletami: jawnością informacji, zapobieganiem powstawaniu konfliktów dzięki możliwości natychmiastowego wyjaśniania nieporozumień. Synteza tych dwóch korzyści prowadzi do kolejnej - wzrostu przewagi konkurencyjnej [Młotek, on-line].

Opinię na temat forum dyskusyjnego wyraziło $11 \%$ ankietowanych. Połowa respondentów wystawiło ocenę negatywna, tyle samo osób pozytywną. Taki rozkład głosów wymaga oddzielnej analizy w innym badaniu. Wideokonferencje oceniło również $11 \%$ pracowników, z czego aż $60 \%$ wypowiedziało się negatywnie, a 40\% pozytywnie. Wynik okazał się niekorzystny dla tego narzędzia komunikacyjnego. Podobną ocenę uzyskały telekonferencje.

Całkowicie zrozumiałym faktem jest niejako promowanie przez pracowników narzędzi, za pomocą których ograniczają nakład czasowy niezbędny do pozyskania informacji. W społeczeństwie informacyjnym, jakim niewątpliwie jesteśmy, informacja oraz dostęp do niej jest rzeczą, o którą warto zabiegać.

Wszystkie rozważania odnosiły się do narzędzi komunikacyjnych rozumianych jako oprogramowanie teleinformatyczne, z którym człowiek obcuje bezpośrednio na swoim stanowisku pracy lub w ramach wykonywania obowiązków służbowych.

Wraz z postępem technicznym ulegają zmianie nawyki i zachowania. To z kolei oddziałuje na sposoby realizacji pewnych tematów w organizacjach. Dobrym przykładem są szkolenia, które jeszcze kilka lat temu oznaczało spotkanie grupy osób w osobnym pomieszczeniu - najczęściej sali konferencyjnej lub szkoleniowej - gdzie następowała wymiana informacji oraz ćwiczenie i doskonalenia umiejętności. Nad prawidłowym przebiegiem szkolenia czuwał trener. Obecnie możliwości w zasadzie są ograniczone tylko przez wyobraźnię i finanse. Szkolenia on-line już od kilku lat są rzeczywistością. Pod pewnymi względami wydają się być nawet wygodniejsze dla pracowników. Uczestnik realizuje program we własnym tempie i w dowolnie wybranym czasie. Szkolenie może również odbywać się w formie prezentacji czy panelu dyskusyjnego, oferując dodatkowe możliwości, jak czat dla uczestników czy wirtualne laboratorium.

Mimo docenienia nowych technologii, pracownicy w badanym obiekcie preferowali szkolenia organizowane $\mathrm{w}$ formie tradycyjnej. Przyczyn takiego stanu rzeczy może być kilka. Po pierwsze, znaczenie może mieć wiek ankietowanych. Osoby starsze trudniej adaptują się do nowych warunków i jest im ciężej korzystać z nowinek technologicznych. W badanej populacji największą grupę stanowiły osoby w wieku od 26 do 35 lat. Przedstawiciele tej grupy wiekowej nie powinni 
mieć problemów podczas uczestnictwa w tego typu szkoleniach. Prócz wieku istotnym elementem mającym wpływ na postrzeganie szkoleń mogą być nawyki i preferencje. Takie aspekty osobowości każdego człowieka są bardzo trudne do zmiany, co nie oznacza, że jest to niemożliwe. W takim przypadku należałoby skupić się na wykazaniu przewagi i korzyści jakie płyną z zastosowania tego modelu. Takie podejście powinno ułatwić i złagodzić proces wprowadzania zmian.

Najbardziej prawdopodobną przyczyną częstego wyboru tradycyjnej formy jest efektywność szkoleń. Powszechnie wiadomo, że do człowieka siedzącego przy komputerze dociera wiele bodźców rozpraszających uwagę. Dodatkowo chęć pozostawania cały czas on-line również nie poprawia naszej koncentracji na prezentowanych materiałach szkoleniowych. Dla przykładu warto przyjrzeć się dwóm urządzeniom dostępnym na rynku: tabletowi oraz e-czytnikowi. Wydawać by się mogło, że skoro na tablecie można czytać elektroniczne książki, a dodatkowo być cały czas on-line, e-czytniki nie mają na rynku szans powodzenia. Okazało się jednak, że bardzo wąska specjalizacja urządzenia oraz odmienna konstrukcja ekranu są tym, co wpływa na sukces urządzeń dedykowanych do czytania elektronicznych publikacji.

Jedną z możliwości dotarcia w firmie do szerszej grupy odbiorców jest witryna intranetowa. Poza standardowymi informacjami wewnętrzne portale wyposażone są w wyszukiwarkę dla pracowników, forum dyskusyjne i chat. Z uwagi na powszechność rozwiązania zdecydowano się na zbadanie opinii pracowników na temat strony intranetowej (rys. 1).

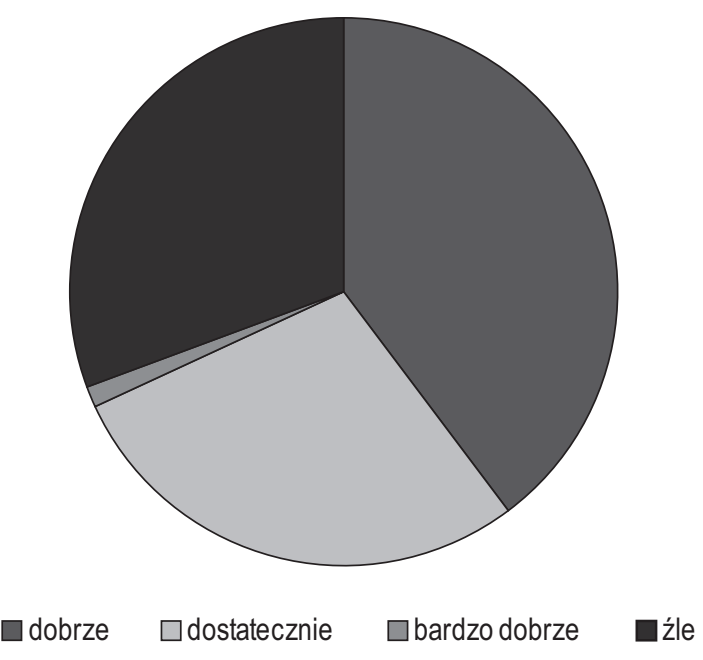

Rysunek 1

Ocena przejrzystości/czytelności strony intranetowej

Źródło: Badania własne. 
Opinie pracowników dotyczące czytelności strony intranetowej były bardzo podzielone. Przede wszystkim niepokojący był fakt, że tylko 1\% respondentów oceniła czytelność strony jako bardzo dobrą. Pozostałe $87 \%$ podzieliło się na trzy - mniej więcej - równe grupy, spośród których najliczniejsza była ta oceniająca stronę intranetową dobrze. Liczyła ona 35\% osób. Pozostałe dwie grupy to osoby, które wystawily ocenę „dostateczną” oraz „negatywną” - z przewagą tej ostatniej. Zasadne byłoby wykonanie badania pogłębionego celem zbadania oczekiwań pracowników. W sytuacji rozważania wprowadzenia zmian w budowie strony intranetowej opinia bezpośrednich odbiorców okazałaby się cenną wskazówką. Wykorzystanie uwag pracowników miałoby szansę bezpośrednio przełożyć się na sukces projektu nowego portalu intranetowego.

\section{Podsumowanie i wnioski}

Analiza wyników badań pozwoliła wskazać na elektroniczną pocztę korporacyjną jako narzędzie dominujące w firmie. Jego skuteczność oraz stopień wykorzystania był bardzo wysoki. Proponując konkretne funkcje do implementacji, największy nacisk położono na aspekt komunikacji w czasie rzeczywistym, gdyż jest to główny kierunek, w jakim już w najbliższej przyszłości to i inne narzędzia będą ewoluowały.

Mimo szybkiego rozwoju elektronicznych środków komunikacji i stałego wzrostu ich wykorzystania, pracownicy bardzo nisko ocenili wideokonferencje. Równie nisko ocenione zostały szkolenia prowadzone w trybie on-line.

Przyszłość jakiegokolwiek narzędzia komunikacyjnego zależy od stopnia jego integracji z pozostałymi, jakie pracownicy wykorzystują w firmie, bezpośrednio na swoim stanowisku pracy oraz na stanowiskach współdzielonych, takich jak np. sale konferencyjne. Im komunikacja za jego pomocą będzie bliższa bezpośredniej rozmowie, tym większa jego efektywność, a co za tym idzie chęć wykorzystania przez pracowników.

Zmianie ulegać mogą wykorzystywane technologie, metody dostępu czy wymagania biznesowe, ale na pewno każdy z tych aspektów zdominowany zostanie przez potrzebę wymiany informacji po pierwsze w czasie rzeczywistym, a po drugie w sposób najbardziej zbliżony do bezpośredniej rozmowy. Umiejętność implementacji funkcji realizujących te potrzeby jest krytycznym czynnikiem sukcesu każdego narzędzia komunikacyjnego. Niezależne bowiem od charakteru pracy, efektywne komunikowanie się jest ważne i niezbędne dla efektywnego działania organizacji i sukcesu jej członków [Stankiewicz 2006, s. 13]. 
Komunikacja wewnętrzna w Polsce według opinii praktyków w tej dziedzinie ma przed sobą dobre perspektywy:

- znaczenie komunikacji wewnętrznej w organizacjach rośnie,

- firmy w Polsce wchodzą w fazę rozwoju wymagającą lepszej komunikacji z ludźmi,

- pracownicy oczekują większej otwartości, co wywiera presję na zarządzających, aby przykładali uwagę do komunikacji wewnętrznej [Raport 2011-2012].

\section{Literatura}

BIELAWSKI P.: Komunikacja wewnętrzna, [w:] www.proto.pl (dostęp: 29.11.2013).

BIENIECKA S.: Badanie zachowań informacyjnych, Wydawnictwo ZPWiM, Warszawa 2013.

GRIFFIN R.W.: Podstawy zarzqdzania organizacjami, PWN, Warszawa 2002, s. 554.

MŁOTEK M.: Od „tuby zarzqdu” do czatów, [w:] www.proto.pl (dostęp: 30.12.2013).

OLĘDZKI J., TWORZYDŁO D. (red.): Leksykon Public Relations, Wydawnictwo NEWSLINE.PL, Rzeszów 2009.

PIATKIEWICZ A.: Komunikacja wewnętrzna, czyli rzecz o Intranecie, [w:] www.proto.pl (dostęp: 28.11.2013).

Raport GFMP i PRoto.pl - Komunikacja wewnętrzna w Polsce 2011-2012.

STONER J.A.F., FREEMAN R.E., GILBERT Jr D.R.: Kierowanie, PWE, Warszawa 1998. http://www.proto.pl/raport_proto (dostęp: 28.11.2013).

GOBAN-KLASS T.: Public Relations, czyli promocja reputacji, Wydawnictwo Rzeczpospolita Business Book, Warszawa 1997. s. 85.

\section{The use of IT tools in internal communication in an enterprise}

\section{Abstract}

Communication tools used by the employees can be compared to a nervous system of any organization. Its lack or inadequacy entail serious consequences leading, in extreme cases, to loss of liquidity and bankruptcy. The study presents ways of internal communication in a large enterprise. The extent of their usefulness has been assessed and exemplified by pkt.pl Polish Telephone Directory. As a result of the surveys, the most effective - according to the employees - IT communication tools were chosen. 